\title{
Detection of Toxoplasma gondii in a free-ranging giant anteater
}

\author{
Thais Oliveira Morgado $^{1^{*}}$ Francielle Cristina Kagueyama $^{2}$ Janaina Marcela Assunção Rosa ${ }^{2}$ \\ Melissa Debesa Belizário² Richard de Campos Pacheco ${ }^{2}$ Valéria Dutra ${ }^{2}$ \\ Sandra Helena Ramiro Corrêa ${ }^{1,2}$ Regina Celia Rodrigues da Paz ${ }^{2}$
}

${ }^{1}$ Universidade Federal de Mato Grosso (UFMT), Av. Fernando Corrêa da Costa, 2367, Boa Esperança, 78060-900, Cuiabá, MT, Brasil. E-mail: thaismorgado@gmail.com. “Corresponding author.

${ }^{2}$ Faculdade de Medicina Veterinária, Universidade Federal de Mato Grosso (UFMT), Cuiabá, MT, Brasil.

\begin{abstract}
Toxoplasmosis is caused by Toxoplasma gondii, an obligatory intracellular protozoan, which establishes acute and chronic infections in birds and mammals, including humans. This note reports, for the first time, the detection and sequencing of DNA from $T$. gondii in the peripheral blood of a young free range giant anteater (Myrmecophaga tridactyla). For the diagnosis, the following methods were used: polymerase chain reaction (PCR) and positive serology (1:800) by means of the modified agglutination test (MAT). Since this species may be consumed by humans and predated by wild felids, its importance is emphasized as a probable source of zoonotic infection, in addition to its possible participation in the infection enzootic cycle. Although, parasitemia has been confirmed in this specimen, it presented no clinical sign of infection.
\end{abstract}

Key words: Myrmecophaga tridactyla, PCR, modified agglutination test, blood.

Deteç̧ão de Toxoplasma gondii em tamanduá-bandeira de vida livre

RESUMO: A toxoplasmose é causada pelo Toxoplasma gondii, um protozoário intracelular obrigatório, que estabelece infecções agudas e crônicas em aves e mamíferos, incluindo humanos. Esta nota relata, pela primeira vez, a detecção e o sequenciamento do DNA de T. gondii em sangue periférico de um filhote de tamanduá-bandeira (Myrmecophaga tridactyla) de vida livre. Para o diagnóstico, os seguintes métodos foram utilizados: reação em cadeia pela polimerase (PCR) e sorologia positiva (1:800) por meio de teste de aglutinação modificado (MAT). Por se tratar de uma espécie que pode ser consumida por humanos e predada por felideos silvestres, sua importância é ressaltada como uma provável fonte de infecção zoonótica, além da sua possível participação no ciclo enzoótico de infecção. Embora a parasitemia tenha sido comprovada neste espécime, ele não apresentava sinais clínicos de infecção.

Palavras-chave: Myrmecophaga tridactyla, PCR, teste de aglutinação modificado, sangue.

Toxoplasmosis is a worldwide distribution disease caused by Toxoplasma gondii, an obligatory intracellular protozoan. This parasite has felids as final hosts, causing acute and chronic infections in a wide variety of intermediate hosts, including humans (DUBEY, 2010).

Identification of $T$. gondii by molecular techniques in new hosts is essential to both clarify its interaction with hosts and indicate environmental contamination (RICHINI-PEREIRA et al., 2016). Toxoplasmosis can be diagnosed by biological, serological, and histological methods or a combination of them (DUBEY, 2010). Despite the serological evidence of infection with $T$. gondii in free-ranging wild animals, their role in the epidemiological chain and species susceptibility to protozoan are not yet well described (VITALIANO, 2014).

The giant anteater (Myrmecophaga tridactyla) population is decreasing, and this species has been classified as "vulnerable" (MIRANDA \& MEDRI, 2010). Therefore, the objective of this study was to describe the first positive case of $T$. gondii detected by PCR in the peripheral blood of a young free-ranging giant anteater.

A female and orphan specimen of a giant anteater (M. tridactyla; approximate age: 10 days; weight: $1.26 \mathrm{~kg}$ ) was attended at the Veterinary Hospital (HOVET), Universidade Federal do Mato Grosso (UFMT), receiving veterinary medical care and breastfeeding. The pup had no contact with 
other species of wild or domestic animals during the period when it was in the hospital. Although, it was clinically healthy, at three months of age it was chemically contained with Ketamine $(8.0 \mathrm{mg} / \mathrm{kg})$ and Midazolam $(0.2 \mathrm{mg} / \mathrm{kg})$ for routine exams, such as hematology, clinical biochemistry, and search for infectious agents in the epidemiological survey of wild animals received at the HOVET-UFMT. Blood collected by venipuncture of the cephalic vein, and the sample so obtained was divided into three aliquots: i) $10 \%$ EDTA tube $(1 \mathrm{~mL})$, ii) tube without anticoagulant $(2 \mathrm{~mL})$, and $i i i)$ microtube $(0.5 \mathrm{~mL})$, depending on the type of analysis. The values for the hematological and biochemical parameters were within normality as expected for the species.

The serum sample was submitted to the modified agglutination test (MAT) for $T$. gondii, being performed according to DUBEY \& DESMONTS (1987). Reagent samples were considered positive at dilutions equal to or greater than 1:25. Antigen obtained from mice peritoneal fluid, previously inoculated with $\mathrm{RH}$ strain tachyzoites, was used. The whole blood sample was submitted to DNA extraction using the phenol-chloroform method (SAMBROOK \& RUSSELL, 2001). Then a PCR was performed, using the universal oligonucleotides TOXO 1 (5'-GGAACTGCATCCGTTCATGAG-3') and TOXO 2 (5'-TCTTTAAAGCGTTCGTGGTC-3') as described by BURG et al. (1989), seeking to amplify a 194 base pair (bp) fragment of the $B 1$ gene species specific for $T$. gondii. The following reagents were used for amplification (final volume: 25 $\mu \mathrm{l}$ ): 8 pmol of each primer; $2.7 \mathrm{mM} \mathrm{MgCl}_{2} ; 1 \mathrm{x}$ PCR buffer (20mM Tris-HCl; 50mM KCl; pH 8.4); 0.2mM DNTPs; $1 \mathrm{U}$ Taq DNA polymerase; and 10ng DNA. The reaction was carried out in a thermocycler(BIO-RAD MyCyclerThermalCycler) with initial denaturation $\left(95^{\circ} \mathrm{C}, 5 \mathrm{~min}\right)$, followed by 30 cycles $\left(95^{\circ} \mathrm{C}, 30 \mathrm{sec}\right)$, annealing $\left(56^{\circ} \mathrm{C}\right.$, $45 \mathrm{sec})$ and extension $\left(72^{\circ} \mathrm{C}, 2 \mathrm{~min}\right)$, with a final extension cycle $\left(72^{\circ} \mathrm{C}, 5 \mathrm{~min}\right)$. Ultrapure water was used for the negative control and genomic DNA (10ng) from the protozoan cell culture was used for the positive control. The control DNA was extracted using the method described above. The amplification products were analyzed in $2.0 \%$ agarose gel electrophoresis, stained with Gel Red ${ }^{\mathrm{TM}}$ (Biotium $^{\circledR} ; 10 \mathrm{~V} / \mathrm{cm}$ ), and observed in ChemiDoc ${ }^{\mathrm{TM}}$ XRS using the ImageLab ${ }^{\mathrm{TM}}$ software. Ladder ${ }^{\mathrm{TM}}$ (Ludwig ${ }^{\circledR} ; 0.1 \mu \mathrm{g} / \mu \mathrm{l} ; 100 \mathrm{bp}$ ) DNA was used as base pair marker.
The sample was positive in PCR. The amplicon thus obtained was purified on the GFX PCR DNA and Gel Band purification kit, sequenced on the ABI 3500 (Applied Biosystems ${ }^{\circledR}$ ) Genetic Analyzer using specific oligonucleotides, and the sequence was finally deposited in the GenBank (No. KU288755). The sequence was also analyzed by the $B L A S T$ (NCBI) program, obtaining 100\% identity with the AF179871 sequence of T. gondii. In the MAT, the serum sample was positive for anti- $T$. gondii antibodies (title: 1:800).

It should be considered that PCR positivity for $T$. gondii will only be observed in peripheral venous blood samples in cases of parasitemia, i.e., when protozoan dissemination or passage occurs in the blood. This may occur in the acute phase of infection or, alternatively, when there is recrudescence of encysted bradyzoites, with possible appearance of clinical signs, such as in situations in which the immune system is affected (DUBEY, 2010).

The T. gondii parasite causes an asymptomatic infection in most hosts due to a rapid induction of the cellular immune response, which results in the control of tachyzoite multiplication and establishment of a chronic infection (DUBEY, 2010). Non-regenerative anemia, neutrophilic leukocytosis, lymphocytosis, monocytosis, and eosinophilia are most commonly observed (LAPPIN et al., 1996). However, the hematological and biochemical parameters remained within the normal range in this case, even during parasitemia.

In this giant anteater, no clinical sign was observed during parasitemia. In this case, stating that parasitemia occurred by toxoplasmosis reactivation due to either recrudescence of the encysted bradyzoites or the acute phase of an infection is uncertain. The absence of clinical signs in this specimen can be explained by strain pathogenicity and virulence, in addition to host immunity. Little is known about the susceptibility of the giant anteater to this infection.

For the first time, Vitaliano (2014) conducted a serological survey, and described anti- $T$. gondii antibodies detected in two freeranging anteaters by the same MAT technique, and their titles $(1: 100$ and 1:800) were similar to that obtained in the present study. Moreover, RICHINIPEREIRA et al. (2016) performed the genotyping of T. gondii in wild mammals killed in traffic accidents on a road (Central-West Region, State of São Paulo, Brazil), and they reported T. gondii DNA in samples of tissues from two M. tridactyla. 
The diagnostic sensitivity of serological tests may be low when they are used in cases of acute toxoplasmosis (GYIMESI et al., 2016). In these cases, the clinical signs may appear before the development of an immune response, and failure can occur in the detection of class $\mathrm{G}$ (IgG) or M (IgM) immunoglobulins at the beginning of parasitemia (CASTILHO-MORALES et al., 2012).

Thus, diagnosis of $T$. gondii by PCR using peripheral blood to detect DNA is imperative in cases in which confirmation of parasitemia in the host is necessary, especially in those with immunological deficiency (ROBERT-GANGNEUX, 2015). In addition, PCR also allows diagnosis in animals with high sensitivity to protozoan infection (which can develop fatal toxoplasmosis) and early detection; although, in the acute phase, prior to antibody production. Therefore, early detection enables treatment in highly susceptible species, such as neotropical primates and giant panda (Ailuropoda melanoleuca) among others (CASAGRANDE et al., 2013; MA et al., 2015).

The positive results obtained from serological tests do not always reflect that the host is infected with $T$. gondii. They only indicate contact with the protozoan. The PCR confirms the presence of parasite DNA (KORNACKA et al., 2016). GYIMESI et al. (2006) conducted a study using different toxoplasmosis diagnostic techniques in a colony of woolly monkeys (Lagothrix lagotricha). Histopathological and biochemical findings showed that death of monkeys was due to fatal toxoplasmosis. Later, these authors were able to perform PCR of DNA extracted from stored serum samples, thus confirming that they were positive for T. gondii. These results showed effective diagnosis through the use of PCR.

Giant anteaters are historically hunted for food in all their territorial distribution, and such practice is part of the culture of some indigenous peoples (MIRANDA \& MEDRI, 2010). Since large felines are natural predators of this species, the sexual phase of $T$. gondii continues in these wild felines as definitive hosts, thus completing the protozoan cycle in the wild environment (DUBEY, 2010).

Thus, the giant anteater can be considered as an intermediate host, being a probable source of infection for humans and wild carnivores through the consumption of raw or undercooked meat from giant anteater. In this case, pathogenicity is related to the $T$. gondii sample virulence of and species susceptibility. Although, parasitemia was confirmed, by amplification of $T$. gondii DNA (GenBank; No. KU288755) and a high antibody title (1:800), we emphasize the fact that this specimen of $M$. tridactyla showed no clinical sign of infection. Therefore, it is impossible to draw a conclusion based only on serological data or DNA detection in tissues from dead animals. Therefore, further studies are suggested on genotyping and pathogenicity of strains of $T$. gondii reported in M. tridactyla.

\section{BIOETHICS AND BIOSSECURITY COMMITTEE APPROVAL}

Approved by the Ethics Committee for Animal Use (CEUA-UFMT; protocol No 23108.017917/12-0).

\section{ACKNOWLEDGEMENTS}

To Coordenação de Aperfeiçoamento de Pessoal de Nível Superior (CAPES); to Conselho Nacional de Desenvolvimento Científico e Tecnológico (CNPq) for the scholarships of V. Dutra and R.C. Pacheco.

\section{REFERENCES}

BURG, J.L. et al. Direct and sensitive detection of a pathogenic protozoan, Toxoplasma gondii, by polymerase chain reaction. Journal of Clinical Microbiology, v.27, n.8, p.1787-1792, 1989.

CASAGRANDE, R.A. et al. Toxoplasmosis in New World primates: Retrospective study of seven cases. Pesquisa Veterinária Brasileira, v.33, n.1, p.94-98, 2013. Available from: <http://www.scielo.br/pdf/ pvb/v33n1/17.pdf $>$. Acessed: Nov. 20, 2016. doi: 10.1590/S0100736X2013000100017.

CASTILHO-MORALES, V.J. et al. Prevalence and Risk Factors of Toxoplasma gondii Infection in Domestic Cats from the Tropics of Mexico Using Serological and Molecular Tests. Interdisciplinary Perspectives on Infectious Diseases, v.2012, p.1-6, 2012. Available from: <http://dx.doi.org/10.1155/2012/529108>. Acessed: Nov. 20, 2016. doi: $10.1155 / 2012 / 529108$.

DUBEY, J.P.; DESMONTS, G. Serological responses of equids fed Toxoplasma gondii oocysts. Equine Veterinary Journal, v.19, n.4, p.337-339, 1987.

DUBEY, J.P. Toxoplasmosis of animals and humans. 2.ed. New York: CRC, 2010. 313p.

GYIMESI, Z.S. et al. Application of assays for the diagnosis of Toxoplasmosis in a colony of woolly monkeys (Lagothrix lagotricha). Journal of Zoo and Wildlife Medicine, v.37, n.3, p.276-280, 2006. Available from: <https://www.ncbi.nlm.nih.gov/pubmed/17319125>. Accessed: Nov. 20, 2016. doi: 10.1638/05-018.1.

KORNACKA, A. et al. The usefulness of direct agglutination test, enzyme-linked immunosorbent assay and polymerase chain reaction for the detection of Toxoplasma gondii in wild animals. Veterinary Parasitology, v.228, p.85-89, 2016. Available from: $<$ https://doi.org/10.1016/j.vetpar.2016.08.010>. Accessed: Nov. 20, 2016. doi: 10.1016/j.vetpar.2016.08.010 
LAPPIN, M.R. et al. Primary and secondary Toxoplasma gondii infection in normal and feline immunodeficiency virus infected cats. Journal of Parasitology, v.82, p.733-742, 1996.

MA, H. et al. Fatal Toxoplasma gondii infection in the giant panda. Parasite, v.22, n.30, p.1-3, 2015. Available from: <https://www. ncbi.nlm.nih.gov/pmc/articles/PMC4626621/>. Accessed: Nov. 20, 2016. doi: 10.1051/parasite/2015030.

MIRANDA, F; MEDRI, I.M. Myrmecophaga tridactyla. Edentata. Washington: The Newsletter of the IUCN/SSC Edentate Specialist Group, 2010 n.11 (2), p.103-104.

RICHINI-PEREIRA, V.B. et al. Genotyping of Toxoplasma gondii and Sarcocystis spp. in road-killed wild mammals from the Central Western Region of the State of São Paulo, Brazil. Revista da Sociedade Brasileira de Medicina Tropical, v.49, n.5, p.602-607,
2016. Available from: <http://dx.doi.org/10.1590/0037-8682-02702016>. Accessed: Nov. 20, 2016. doi: 10.1590/0037-8682-0270-2016.

ROBERT-GANGNEUX, F. et al. Molecular diagnosis of toxoplasmosis in immunocompromised patients: a three year multicenter retrospective study. Journal of Clinical Microbiology, v.53, n.5, 2015. Available from: $<$ http://jcm.asm.org/ content/53/5/1677.short>. Accessed: Nov. 10, 2016. doi: 10.1128/ JCM.03282-14.

SAMBROOK, J.; RUSSELL, D.W. Molecular cloning: a laboratory manual. 2.ed. New York: CsHL. 2001. 2100p.

VITALIANO, N.S. et al. Serologic evidence of Toxoplasma gondii infection in wild birds and mammals from Southeast Brazil. Journal of Zoo and Wildlife Medicine, v.45, n.1, p.197-199, 2014. 